\title{
The Outlook for Changes in Federal Taxation
}

\author{
by MURRAY L. WEIDENBAUM
}

\begin{abstract}
Murray L. Weidenbaum is Edward Mallinckrodt Distinguished University Professor of Economics at Washington University, St. Louis, Missouri. He has served as a Fiscal Economist in the Bureau of the Budget and more recently as Assistant Secretary of the Treasury. Among other positions, he is currently a member of the Board of Editors of the Journal OF EConomic Issues and Publuus, the Journal of Federalism, a columnist for Dun's Review, and Adjunct Scholar at the American Enterprise Institute for Public Policy Research.

This paper was presented at the Annual Conference of College and University Professors of the Federal Reserve Bank of St. Louis on November 3, 1972.
\end{abstract}

$\mathbf{N}$ year of substantial change in the Federal tax system. This is not just a political forecast that I am making. It is also an economic one. There are some hard fiscal facts of life that the next Administration in Washington, be it Republican or Democrat, will inevitably be facing.

To put the situation in a nutshell, our collective appetites for new and expanded government spending programs have outrun the ability of the existing tax system to pay for them. We literally have mortgaged available Federal revenues for many years into the future. The Federal Govermment is running a $\$ 30-\$ 35$ billion deficit this fiscal year. Although some improvem ment can be expected next year, another full-employment deficit is likely.

And still more new demands on the public purse are already clearly visible. The most notable one is in the area of public school finaneing, where the courts are requiring the raising of outlays for educating children in poor areas.

One pressure on the tax system is thus clear - the need to raise more revenue. But simultaneously, there is another pressure on the Federal tax structure - the drive for tax reform. Much of the public discussion is uninformed and some borders on the hysterical. Yet, there is strong voter support for Congress taking a new look at the entire complex of special benefits, complicated provisions, and altemative tax treatments of income which take up so many hundreds of pages of the Internal Revenue Code.
Senior members of the House of Representatives Ways and Means Committee have stated that tax reform will be high on the Committee's agenda in the new Congress. Let us take up three major types of changes which have been suggested in the current public debate: (1) reducing the incentives to investment, (2) changing individual deductions and exemptions, and (3) tightening up on tax-exempt or "preferred" income.

\section{Reducing the Incentives to Investinent}

Quite understandably, many investors and businessmen were badly shaken by recommendations to eliminate the special tax treatment of long-term capital gains and simultaneously to repeal the investment credit and the recent liberalization of depreciation allowances. Such a combined assault on the ability and incentive to invest undoubtedly would adversely affect business sentiment and tend to reduce investment. However, too many people were overreacting.

I do not consider the enactment of this radical package at all likely. Maybe the "loophole closers" are oblivious to the side-effects of such actions, but the tax-writing committees of the Congress are not. But some reduction in these tax incentives is likely.

At present the odds favor increasing the minimum holding period in order to qualify for long-term capital gains treatment from six months to one year. Logic does force us to admit that treating a six-month investment as "long term" is an anomoly. 
A related alternative being considered is a graduated tax rate depending on the length of the holding period. This would be a step towards an incomeaveraging approach. Another prime candidate for change is to tax capital gains at death. This would encourage older people to sell assets on which sizable gains have accrued. At present, their estates are not liable for any capital gains tax.

Also, the alternative tax on capital gains - which the taxpayer can choose instead of one-half of his regular tax rate - may be raised again. The 1969 Tax Reform Act increased the alternative rate from 25 percent to the present 30 percent. I believe that it is less likely that the Congress will repeal the recentlyrestored investment credit or the liberalized depreciation (ADR) system. Certainly, I believe that both actions are an improbable combination.

\section{Changing Individual Deductions and Exemptions}

No doubt we will continue to hear a great deal of talk about how "regressive" the current method of deductions and exemptions is on the Federal individual income tax. In general, I do not expect anything to come of it. Most of these so-called "loopholes" (Table I) go to average-income individuals.

The major ones in terms of revenue loss to the Treasury are the tax deductibility of state and local taxes and interest on home mortgages. These cost the Government over $\$ 11$ billion a year, compared to the less than $\$ 1$ billion for the depletion allowances that we hear so much about.

I just do not see much possibility of eliminating these tax breaks to individuals. The national desire to encourage home ownership continues unabated. The need to soften the impact of rising property and other state and local taxes is surely growing. Yet, we must note the special case of tax benefits to high-income housing investors; in this area, considerable sentiment is building up for reducing the tax advantages of these essentially commercial transactions.

If anything, I would expect the general tax aids to individuals to increase. The idea of a tax credit for parochial and other private school tuition is gaining favor. Property tax relief - for homeowners but not for business - has become a stock fixture in every political platform. One method of achieving that objective is a tax credit for property (or all state-local) taxes. A credit would avoid the regressive feature of the present deduction method, whereby $\$ 1$ of local taxes brings

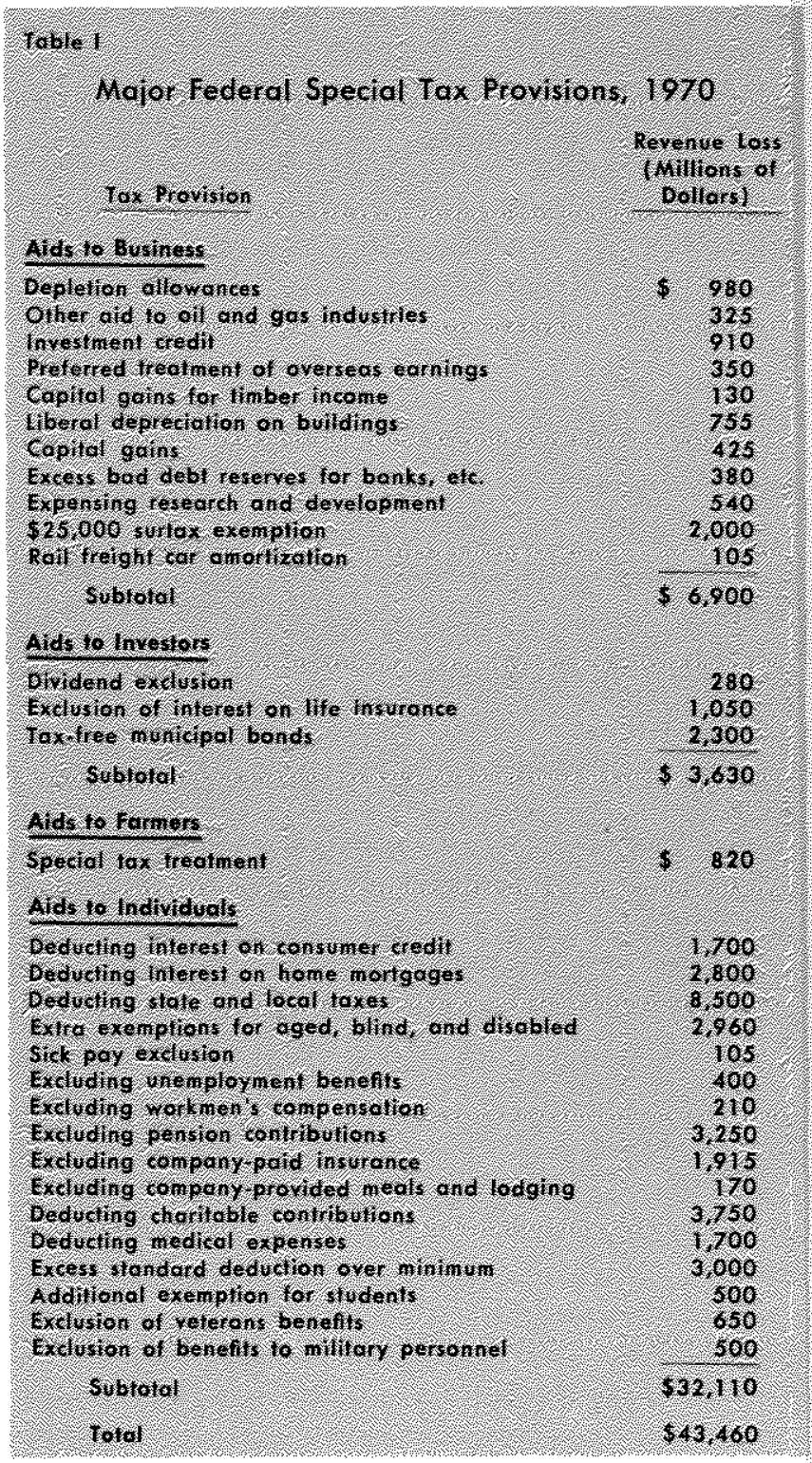

a higher tax saving to the upper bracket Federal tax payer than to the lower bracket individual.

Another way of dealing with this problem would be to introduce a new system of Federal grants to school districts. This would permit the elimination or at least reduction of the local school property tax. But any of these alternatives of course would put a considerable burden on the U.S. Treasury. Hence, they would increase the likelihood of a general tax increase or the imposition of a new tax.

\section{Tightening Up on Tax-Exempt or "Preferred" Income}

The Tax Reform Act of 1969 established a 10 percent minimum tax on various categories of so-called 
"preferred income" which hitherto had escaped Federal taxation altogether. A live possibility is increasing the rate, to perhaps 20 percent. Also, the minimum tax may be extended to other categories of exempt income, notably interest on municipal and state bonds.

I do not believe that tax-exempt bonds will be eliminated, but I do attach considerable probability to the creation of a new type of taxable municipal bond, thus reducing the relative importance of the taxexempt municipals. Such a development would require a Federal interest subsidy to the issuer to cover the difference between the higher interest rate for the taxable bonds and the lower interest rate for taxexempts. This new supplementary way of financing state and local governments is gaining support from many who believe that the tax-exempt market will be too small to meet the capital financing needs of states and localities in the years ahead.

The income of foreign subsidiaries of American corporations also may face rougher tax treatment. One of the most frequently suggested changes is to tax such "foreign" income as it is eamed, rather than the present arrangement of waiting until it is repatriated to the United States. This issue is part of a larger question of changing public attitudes toward multi-national corporations and other aspects of overseas operations of American firms. ${ }^{1}$

Although I do not believe the facts support the issue, many labor groups are concerned about the socalled "export" of American jobs and are pushing pro. tectionist legislation. If anything, these overseas operations have a favorable effect on our balance of trade and our balance of payments. But economic logic does not always sway political decision-making.

\section{Tax Increases or Expenditure Reductions}

Reforming the Federal tax structure may be good for the soul - of some. It may serve the useful purpose of improving the equity of the revenue system and thus increasing voluntary taxpayer compliance. But the net amount of new revenue that it will produce is likely to be very limited. In 1969 , the reforms were coupled with so much tax relief that the net effect was a substantial loss of revenue to the Treasury. I doubt that the reform measures enacted in the near future will provide the large sums that the Treasury will require.

\footnotetext{
1See Murray L. Weidenbaum, "Tariffs, Quotas - Or What?", Dun's Review (September 1972), p. 11.
}

Another alternative of course is to reform the expenditure side of the budget. The Administration has a major effort underway right now. The failure of the Congress to enact a $\$ 250$ billion expenditure ceiling turns out not to be critical. The power of the President to reduce expenditures below the amounts appropriated (so-called "impounding" of funds) is based on both pre-existing legislation (the Antideficiency Act) and well-established custom. Personally, I would have preferred Congressionally-imposed restraint on its own appropriations. An expenditure limit permits Congress to appropriate to their hearts' content, passing the buck to the President to accomplish the unpleasant task of making the actual reductions.

A systematic review of Federal program and spending commitments might be very fruitful. Much could be done in the way of removing subsidies which have long since outlived their original justifications. Many of these programs are vestiges of the 1930s or the 1940s. They are hardly relevant to the priorities of the $1970 \mathrm{~s}$. Rereading the original justifications is like hearing an echo from a different age:

(1) The Davis-Bacon Act was enacted to deal with the problem of low wages in the construction industry - low wages in the building trades in the 1970s?

(2) The program of stockpiling "strategic" materials was intended to deal with the lack of an inventory of metals for extended war production-protracted trench warfare in the 1970s?

(3) The program of supplying low-interest loans by the REA was intended to deal with the lack of electricity on American farms - no lighting in the 1970s?

These programs - and many like them - should be given an honorable discharge or, better yet, a suitable burial. The problem of course is that the recipients of these special benefits constitute entrenched pressure groups which are determined to fight to keep their special privileges.

But if Congress does not cut back substantial amounts of these fiscal sacred cows, the resultant pressures will be quite clear - for a new tax, such as a value added tax (VAT) or for a substantial increase in the Federal income tax. The VAT has many pluses and minuses. It encourages efficiency in the use of resources and meshes with the tax systems of our European trading partners; it is regressive and inflationary. However, it does represent one of the last unused tax sources available to the Federal Government. 
With reference to the altemative of increasing the yield of the individual income tax, there may be much justification for a basic revision of the entire rate structure. But that approach opens up such a can of worms that it likely would delay the entire legislative process. Thus, we seem to be getting used to the simpler approach of a single percentage surcharge on each individual's and corporation's basic tax liability.

Of course we should not underestimate the possibility of inaction - on the part of Congress and/or the Executive Branch. The resultant increase in inflationary pressures would put more of the stabilization burden on our friendly Federal Reserve System, as well as complicate the process of dismantling wage and price controls.

\section{Conclusion}

Whichever view prevails - the fiscal liberals who are more interested in closing all those "Ioopholes" or the fiscal conservatives who are concerned with the rising Federal deficits - 1973 is indeed likely to be a year of considerable action in the field of Federal taxes. Any actual changes voted, however, - particu larly those raising revenues - may not become effective until 1974, when the economy may be turning soft!

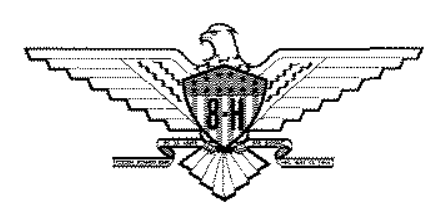

